\title{
Importance of the artificial light field around offshore petroleum platforms for the associated fish community
}

\author{
Sean F. Keenan ${ }^{1, *}$, Mark C. Benfield ${ }^{2}$, Jason K. Blackburn ${ }^{3}$ \\ ${ }^{1}$ Coastal Fisheries Institute, and ${ }^{2}$ Department of Oceanography \& Coastal Sciences/Coastal Fisheries Institute, 2179 Energy, \\ Coast \& Environment Building, Louisiana State University, Baton Rouge, Louisiana 70803, USA \\ ${ }^{3}$ World Health Organization Collaborating Center for Remote Sensing and GIS for Public Health \& Department of \\ Geography and Anthropology, Louisiana State University, Baton Rouge, Louisiana 70803, USA
}

\begin{abstract}
Offshore petroleum platforms in the northern Gulf of Mexico provide a unique environment for many reef-associated and pelagic fish species; however, the factors that contribute to increased localized fish abundance remain poorly quantified. All manned platforms possess large floodlights for nighttime operations and these also illuminate the surrounding waters. Two platforms (MC582 and ST151), located off the Louisiana coast, were examined to quantify this artificial light field. A multi-spectral radiometer instrument package was used to record subsurface irradiance along a regularly spaced grid around each platform. Spectral patterns indicated that the predominant source of underwater light near MC582 was the natural gas flare, while floodlights predominated in the water beneath ST151. Irradiance profiles $\left(\log _{10}\right.$ photosynthetically active radiation) indicated that 10 to 1000 times more light was present near the platforms compared to open water control sites and that light levels decreased with increasing depth. Irradiance values were interpolated to estimate the 3-dimensional underwater light field and volumes were constructed based on published visual thresholds for 3 larval/juvenile fish taxa. Results suggest that platforms provide an enhanced foraging environment for larval, juvenile and adult fishes by providing sufficient light to locate and capture prey, as well as by attracting and concentrating positively phototaxic prey taxa.
\end{abstract}

KEY WORDS: Petroleum platform - Gulf of Mexico - Light field · Fish community · Irradiance · Kriging Resale or republication not permitted without written consent of the publisher

\section{INTRODUCTION}

The northern Gulf of Mexico (Gulf) contains over 3800 petroleum platforms, the highest number in the US (Minerals Management Service: www.gomr.mms. gov/). Offshore petroleum platforms provide a unique environment for fishes and macroinvertebrates and these structures have been described as fish attraction devices (FADs) or de facto artificial reefs (Hastings et al. 1976, Scarborough-Bull \& Kendall 1994, Stanley \& Wilson 1997, Love et al. 1999, US Geological Survey 2002). Many platforms have served as study sites for research on adult fishes (Hastings et al. 1976, Franks
1999, Stanley \& Wilson 2000, Keenan et al. 2003) as well as larval and juvenile fishes (Tolan 2001, Hernandez et al. 2003, Lindquist et al. 2005). While it is known that fish density is elevated in proximity to platforms and other structures relative to open water areas of the Gulf, the mechanisms that serve to concentrate fishes around these structures remain poorly understood. Rountree (1990) and Franks (1999) suggested that platforms (and other FADs) may provide orientative cues, provide shelter from predators, and enhance feeding efficiency. Understanding factors such as these is crucial for addressing the debate over whether platforms merely attract fishes or provide 
sufficient resources to support larger populations (also known as the attraction versus production issue; Bohnsack 1989, Lindberg 1997, Shipp 1999). To this end, Franks (1999) suggested that investigations of the physical gradients around platforms would elucidate factors influencing the distribution of pelagic fishes. One factor that has received little attention in platform-associated fish studies is the influence of the artificial light field.

The structural configuration of offshore petroleum platforms varies, depending primarily on the water depth (Olney 1981). Platforms on the continental shelf commonly possess a fixed-leg steel frame, which extends from the seafloor to above water level. Platforms over the outer continental shelf or slope are often larger, semi-submersible structures called spars or tension leg platforms, which are secured by cables to the seafloor. In general, platforms that have live-aboard personnel are well illuminated by exterior floodlights that assist in nighttime operations and aid navigation. These floodlights, located between 20 and $40 \mathrm{~m}$ above the water surface, illuminate the surrounding water as well as the superstructure. Unmanned structures usually have minimal aid-to-navigation lights only. Another illumination source can be the natural gas flare stack that periodically burns off excess natural gas or other petroleum products (Olney 1981). The light produced from flare stacks and floodlights can often be observed several miles away from the platform.

Many species of pelagic and reef-associated fishes have been documented near platforms. Adult species have been identified and enumerated using various methods such as diver surveys (Hastings et al. 1976, Scarborough-Bull \& Kendall 1994), net trawls (Gallaway 1980), remotely operated vehicles (Stanley \& Wilson 1997, Love et al. 2000), and hydroacoustics (Stanley \& Wilson 1996, 1997, Wilson et al. 2003). Nets and light traps have been used to examine juvenile and larval fishes (Tolan 2001, Hernandez et al. 2003, Lindquist et al. 2005). Common functional groups around platforms in the northern Gulf include predators: mackerels (Scombridae), jacks (Carangidae), snappers (Lutjanidae), and groupers (Serranidae); forage fishes: herrings (Clupeidae), anchovies (Engraulidae), and codlets (Bregmacerotidae); and reefdwelling species: grunts (Haemulidae), blennies (Blenniidae), tangs (Acanthuridae), and damselfish (Pomacentridae). The positive, phototactic nature of many marine fishes has been cited as one potential explanation for their increased abundance around platforms (Hastings et al. 1976, Stanley \& Wilson 1997 , Lindquist et al. 2005); however no measurements of the underwater light field around platforms have been conducted.
Because of the prevalence of illuminated platforms in the Gulf and the lack of information on the distribution of the nocturnal artificial light field around these structures, the present study was designed to assess this phenomenon using a spatially-explicit approach to quantify and map the subsurface light intensity. Our objectives were to (1) evaluate the visible spectrum emitted from the lights of 2 representative platforms, (2) examine the degree to which light penetrates the surrounding waters, (3) visualize the 3D underwater light field, and (4) speculate on the potential influence that platform lights may have on the associated fish community.

\section{MATERIALS AND METHODS}

Sampling sites. Offshore sampling trips were made during August 2004 to 2 platforms located west of the Mississippi delta (Fig. 1). Platform-based sampling was conducted at the South Timbalier 151 platform (ST151, 28.616 ${ }^{\circ} \mathrm{N}, 90.250^{\circ} \mathrm{W}$ ) the evening/night of 17 to 18 August, which was again surveyed by boat during the evening/night of 25 to 26 August. The ST151 platform is a mid-shelf platform (40 m water depth) that consists of 6 interconnected fixed-leg structures. The Mississippi Canyon 582 'Medusa' platform (MC582, $28.392^{\circ} \mathrm{N}, 89.454^{\circ} \mathrm{W}$ ) was surveyed by boat during the evening/night of 18 to 19 August. This tethered, floating spar structure is located on the continental slope at a water depth of $678 \mathrm{~m}$. Both platforms are manned structures producing petroleum and natural gas.

Light measurements. Light measurements were recorded with a Biospherical Instruments ${ }^{\odot}$ PRR-2600 profiling reflectance radiometer (profiling unit). The PRR-2600 measures downwelling irradiance at 7 wavelengths $(412,443,490,510,555,665,683 \mathrm{~nm})$ and photosynthetically active radiation (PAR) integrated over 400 to $700 \mathrm{~nm}$. The PRR-2600 also records water pressure and temperature. Irradiance above the water surface was measured with a Biospherical Instruments ${ }^{\circledR}$ PRR-2610 surface reference sensor (surface unit). During deployments, light readings from both instruments were recorded in real time on a laptop computer running Biospherical Profiler ${ }^{\circledR}$ software (v 1.4.4).

Underwater irradiance was measured by lowering the profiling unit by hand at 30 to $40 \mathrm{~cm} \mathrm{~s}^{-1}$ to approximately $20.5 \mathrm{~m}$ while recording at $5 \mathrm{~Hz}$. During boat sampling at both platforms, a twilight deployment was conducted at approximately 19:00 (all times are local time: GMT $-5 \mathrm{~h}$ ) and the night surveys ran from 22:00 to 02:00 h. Platform-based sampling from ST151 consisted of making deployments from 5 of the 6 platform structures between 22:00 and 01:00 h. These deployments were conducted from the decks, which were 


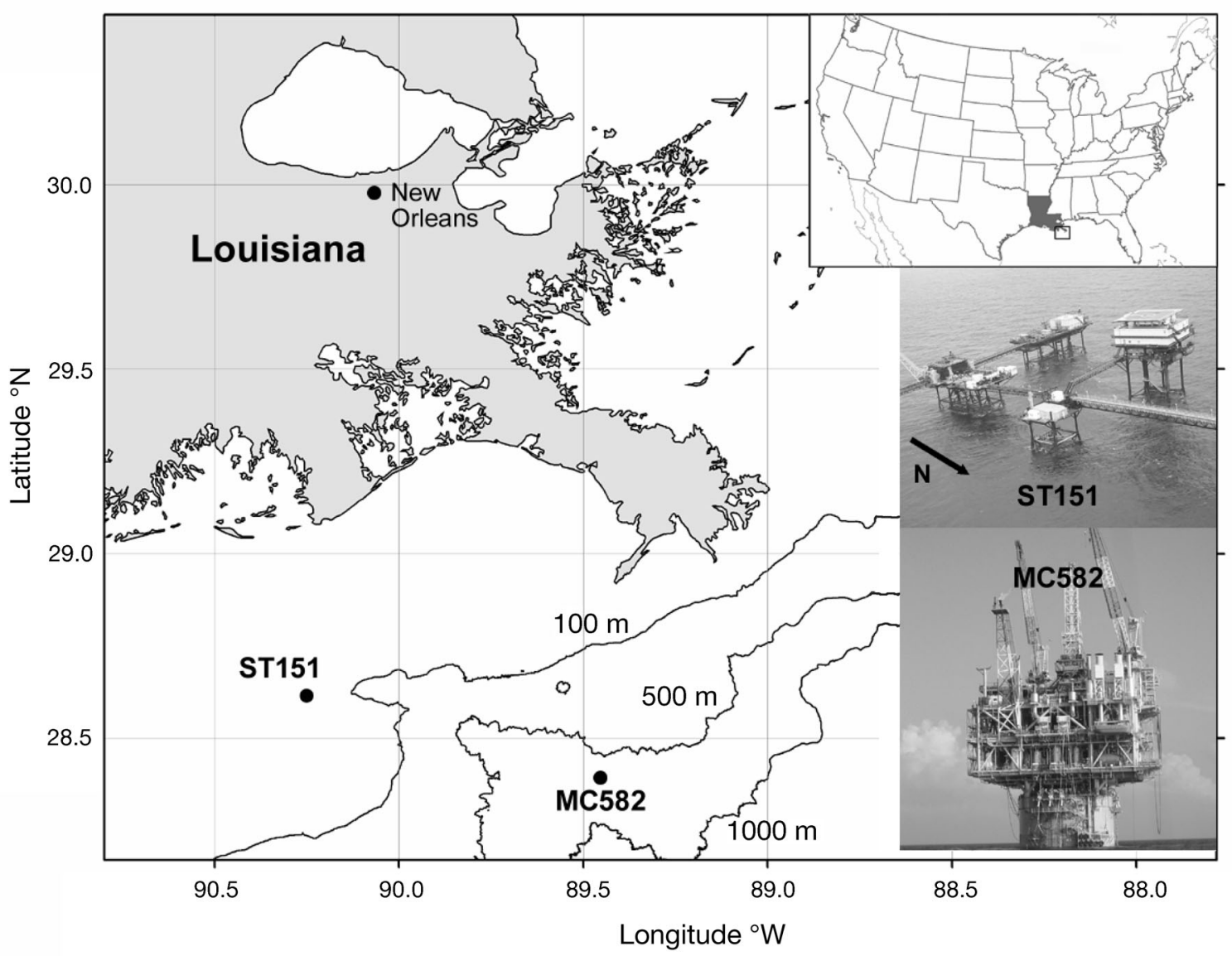

Fig. 1. Southern Louisiana (Gulf of Mexico), indicating locations of study sites ST151 and MC582. Contour lines indicate the 100, 500 and $1000 \mathrm{~m}$ isobaths. Insets indicate location of Louisiana in continental USA and show photos of respective platforms

located approximately $3 \mathrm{~m}$ above the water surface. Local sunset occurred from 18:37 to $18: 39 \mathrm{~h}$ between 17 and 18 August and from 18:31 to 18:32 h between 25 and 26 August (US Naval Observatory, http://mach. usno.navy.mil/). The profiling unit was lowered into the interior of the jacket structure as deep as possible while avoiding subsurface crossmembers. The surface unit was mounted on a handrail adjacent to the deployment location. Sampling near the MC582 platform occurred only from the boat, and the surface unit was fixed to a mast positioned well above the boat deck and cabin and aimed upwards.

Vessel-based irradiance measurements were collected in a grid pattern using the individual platforms as the central point. In the case of ST151, the central point of the entire complex was used as a reference location. The spatial extent of the grid surfaces was designed to extend beyond the likely extent of the artificial light field. Grid surfaces were developed using Field Rover II ${ }^{\circledR}$ GIS mapping software (SST) and ArcGIS 8.3 (ESRI). A 75-m grid cell size was used to sample ST151, while a 100-m cell size was used to sample MC582. Point maps of grid cell centroids were uploaded to 2 personal data assistant (PDA) handheld computers running PDA-GIS software (ArcPad 6.0, ESRI) and CF-GPS units (Teletype) to permit navigation to specified sampling locations. Using the PDA, the vessel captain navigated to the centroid of each cell, and sampling was initiated. In order to account for vessel drift and pinpoint the location of each sample collection, the vessel location was recorded at the start and end of each irradiance cast using the second PDA. Following the completion of each vessel survey around a platform, an 'open water' deployment was conducted at a distance of at least $1.5 \mathrm{~km}$ from the respective platform (and any other neighboring platform) to measure ambient irradiance.

Light meter analysis. The Biospherical software records raw data as voltage which is converted to irradiance $\left(E_{d z}(\lambda) ; \mu W \mathrm{~cm}^{-2} \mathrm{~nm}^{-1}\right.$ or $\left.E_{d z}(P A R) ; \mu E \mathrm{~cm}^{-2} \mathrm{~s}^{-1}\right)$ $(1 \mathrm{E}=1 \mathrm{~mol}$ of photons, $\mathrm{dZ}$ is irradiance at depth $\mathrm{Z}$ ) after calibration. Prior to each series of deployments, black covers were placed on the sensors to record a dark interval at the water surface. This provided a correction for both depth and complete darkness. Corrected measurement of irradiance, depth, latitude and longitude 
were exported into Matlab (Mathworks) for subsequent processing. Measurements were averaged into $0.50 \mathrm{~m}$ depth bins between 0.05 and $20.50 \mathrm{~m}$, with each value representing the mean of all values in the depth bin at the bin mid-depth. Only downcast data were used here.

Spectral comparison. To evaluate the source of light reaching the water and to distinguish between artificial and natural light sources, a comparison was conducted of the spectral distribution over the 7 wavelengths recorded by the surface unit. For ST151, surface irradiance $\left(E_{\mathrm{d} 0}, \mu \mathrm{W} \mathrm{cm} \mathrm{cm}^{-2} \mathrm{~nm}^{-1}\right.$, where $\mathrm{d}_{0}$ is irradiance at depth zero) was recorded beneath 5 of the 6 platforms where the primary source of light was the floodlights from overhead decks. A quarter moon occurred during the first half of the vessel-based ST151 survey, however the moon set before measurements were completed. To quantify the spectral signature of the moonlight, an open water record under the moon was conducted with the surface unit before the start of the survey $(21: 30 \mathrm{~h})$. This moonlight record was conducted in addition to the twilight record (18:51 h). The results from the moonlight record were compared to surface unit records collected from ST151 sites during the initial portions of the survey. There was a new moon during the MC582 survey; therefore spectral comparisons were performed using data from the twilight (18:54 h), platform, and open water records.

Spatial extent of light. We used $\log _{10}$ PAR irradiance $\left(\mathrm{E}_{\mathrm{dz}} \mathrm{PAR}\right)$ collected by the profiling unit to examine the spatial distribution of light around the 2 platforms. Ordinary point kriging was used to interpolate measured irradiance values on a regularly spaced 3D grid. Kriging is a probabilistic, geostatistical technique commonly used to interpolate estimated data values across a regular grid from irregularly spaced observations (e.g. Bailey \& Gatrell 1995, Greene et al. 1998). We used a 61920 cell volume (42 longitude $\times 39$ latitude $\times 40$ depth cells) for MC582 and a 43560 cell volume $(33 \times 33 \times 40$ cells $)$ for ST151. Each grid had resolutions of 9.8, 11.1, and $0.5 \mathrm{~m}$ for longitude, latitude, and depth, respectively. For each deployment, 3D point kriging was performed on the PAR irradiance and the corresponding longitude, latitude, and depth value using the 3D kriging package Easy Krig 3.0 (ftp://globec.whoi.edu/pub/software/ kriging/easy_krig/). Variogram modeling was performed within EasyKrig to estimate the appropriate spatial autocorrelation model for kriging. Least-squared fitting (Matlab Optimization Toolbox) was used to obtain the model that best fit the data and the resulting kriging output was evaluated for goodness of fit using EasyKrig's Q1 and Q2 parameters. A generalized exponentialBessel model provided the best fit to the semi-variogram model for the PAR irradiance data for each survey. Details of the variogram model parameters are provided in Table 1.
The kriging procedure also produces an estimate of error variance for each predicted irradiance value. We normalized the error variance by dividing by the maximum error variance; therefore as error variance increases (approaches 1), there is less confidence in the kriged estimate. Cells which contained an error variance of 0.15 or higher were considered unreliable values and were excluded from the kriged map. Finally, the predicted irradiance values within each grid were visualized in 2 and 3-dimensions using Matlab.

Irradiance profiles. Depth profiles were obtained for PRR-2600 deployments during vessel-based surveys around each platform by calculating the mean PAR downwelling irradiance values within $0.5 \mathrm{~m}$ depth bins. Representative profiles were calculated for MC582 with a transect from NW to SE (with Stn d14 located closest to the structure), at an open water deployment approximately $1.5 \mathrm{~km}$ north of the platform, and for the twilight deployment. For the ST151 complex, representative profile sites were selected to display the range of light intensity encountered during the survey, since the platform is comprised of multiple structures and a transect across the survey would not clearly illustrate this range. The open water deployment for ST151 was completed at the end of the survey, approximately $1.5 \mathrm{~km}$ east of the platform.

Fish irradiance thresholds. A literature search was conducted to identify light intensity thresholds necessary for various behaviors by larval and juvenile fishes. Species were selected that were representative of taxa reported near platforms in the northern Gulf (Lindquist et al. 2005). Published studies were identified for 6 teleost families: Scombridae, Carangidae, Sciaenidae, Pomacentridae, Clupeidae, and Engraulidae. The minimum light threshold required for behaviors such as feeding and schooling was converted to the same PAR irradiance terms used here $\left(E_{d z}, \mu E \mathrm{~cm}^{-2} \mathrm{~s}^{-1}\right)$ using conversions in Valiela (1984).

Three studies were selected from the above search to estimate the extent to which light from platforms may affect specific fish behavior. These threshold values were used to calculate the volume of water within

Table 1. Variogram model parameters for $\log _{10} \mathrm{PAR}$ kriging for MC582 and ST151 platform surveys. PAR: photosynthetically active radiation

\begin{tabular}{|lll|}
\hline Parameter & MC582 & ST151 \\
\hline Model & General exponential & $\begin{array}{c}\text { General exponential } \\
\text { Bessel }\end{array}$ \\
& 0.028 & 0 \\
Nugget & 1.134 & 1.225 \\
Sill & 2.200 & 1.770 \\
Power & 0.490 & 0.538 \\
Length & 0 & 0 \\
Hole size & 0 & \\
\hline
\end{tabular}


which irradiance values were sufficiently high to permit the specific behavior to occur. In each case the specific threshold was used to identify an isosurface in the kriged volume for each platform. Then, all cells that contained irradiance values above the threshold were enumerated and this sum was multiplied by $54.4 \mathrm{~m}^{3}$ cell $^{-1}$ (see grid cell definitions above) to give a speciesspecific irradiance volume.

\section{RESULTS}

\section{Trip conditions}

Each boat survey experienced different sea-states and currents that influenced the captain's ability to guide the vessel to target sampling locations. The trip to MC582 was conducted in 0.6 to $1.2 \mathrm{~m}$ seas with a strong (approximately $80 \mathrm{~cm} \mathrm{~s}^{-1}$ ) northeast current as estimated from vessel-drift vectors. This caused drift during profiling unit deployments and accounted for the lack of deployments for the southern portion of the survey (Fig. 2a). During the survey near ST151 the sea-state was calm and there was little drift (average current of $27 \mathrm{~cm} \mathrm{~s}^{-1}$ ); therefore all deployments were completed at regularly spaced intervals for this survey (Fig. 3a).

\section{Spectral comparison}

The underwater, nocturnal light fields around both platforms were dominated by wavelengths consistent with platform sources. The spectral characteristics of the light in the vicinity of the 2 platforms differed from the light measured during the 2 twilight records, which were both similar (Figs. 2b \& 3b). The predominant light from MC582 was from a bright natural gas flare. Record d14 (Fig. 2d) was collected very near the platform on the same side as the flare and had intensity levels 10 times greater than those at the edge of the survey. The increase in irradiance on the orange/red end of the spectrum (i.e. 665 and $683 \mathrm{~nm}$ ) corresponded to the flare's visible color. The first 5 records (Fig. 2e) conducted along the northernmost survey transect possessed spectral patterns similar to those of Stn d14 although they were less intense. The record taken from the open water away from the platform (Fig. 2c) was less intense and showed no similarity with the platform light. For ST151, the spectral characteristics of the light measured near the platform were different and the illumination was more intense than light measured from moonlight (Fig. 3c). Measurements of light had a nearly identical spectrum among the 5 platform-based records (Fig. 3d) although intensity varied.
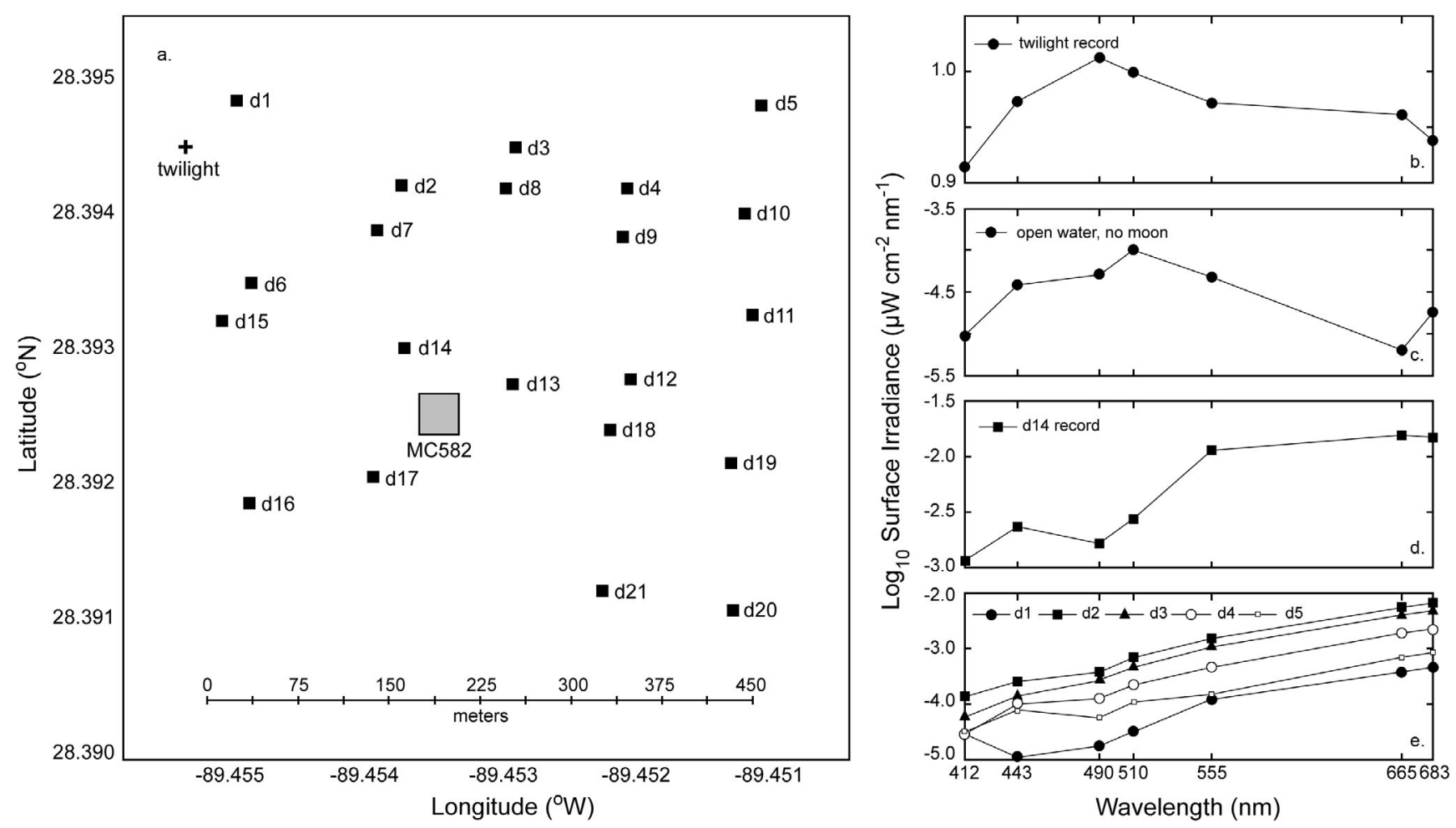

Fig. 2. Spectral characteristics of ambient light recorded by surface detector near site MC582. (a) Deployment sites (d1-d21); $(\mathrm{b}-\mathrm{e}) \log _{10}$ irradiance records from (b) twilight (19:00 h), (c) open water without a moon, (d) d14 site which was directly below the flare, and (e) successive records along northernmost transect (i.e. d1-d5). Location of open water record is not shown and was $\sim 1.5 \mathrm{~km}$ north of the platform 

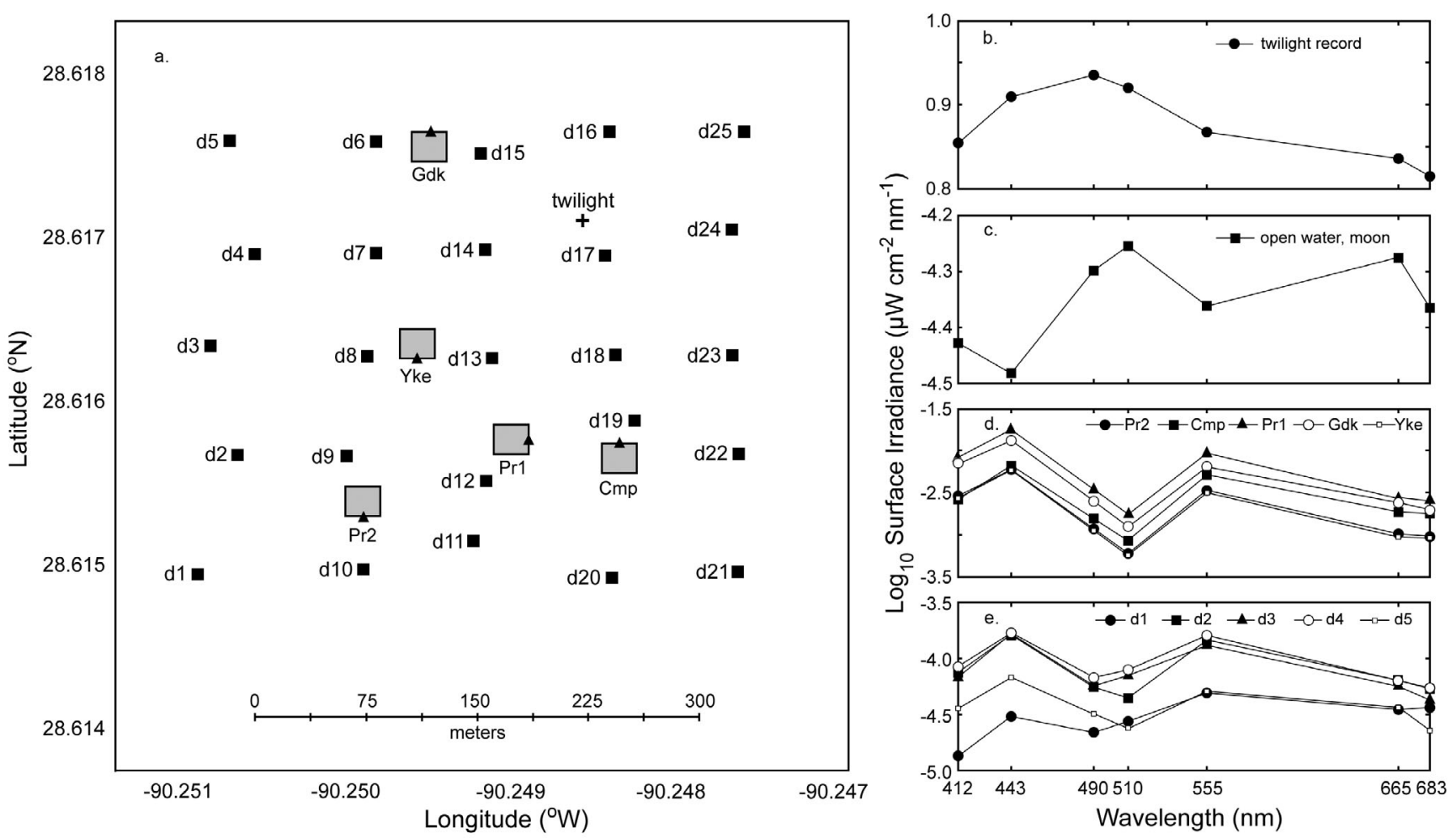

Fig. 3. Spectral characteristics of ambient light recorded by surface detector near ST151. (a) Deployment sites (d1-d25) with platform-based records indicated by black triangles, (b-e) $\log _{10}$ irradiance records from (b) twilight (19:00 h), (c) open water under half-moon, (d) platform-based records, and (e) successive records along western transect (i.e. d1-d5). Location of open water record is not shown and was $\sim 1.5 \mathrm{~km}$ east of the platform. Gdeck, Yank, Prod1, Prod2, Comp: individual structures within ST151 complex

The western transect (Fig. 3e) had the same spectrum pattern except for d1, which was probably dominated by moonlight with less light coming from the platform.

\section{Spatial irradiance patterns}

The pattern of irradiance around both platforms revealed the strong, localized influence of the artificial light from the platforms. At MC582, the light field was concentrated around the structure and to the northwest (Fig. $4 \mathrm{a}-\mathrm{C}$ ), which was consistent with the location of the flare stack. The enhanced irradiance to the north of latitude $28.394^{\circ} \mathrm{N}$ appears to be an artifact of the kriging routine. Irradiance from the 4.75 and $9.75 \mathrm{~m}$ depth strata (Fig. 4b,c) reveals that the light from the flare extended below $10 \mathrm{~m}$ and that the spatial area influenced by this light was progressively closer to the platform with increasing depth. For reference, $\log _{10}$-transformed light measurements from the open water deployment around this platform were -8.7 $(0.75 \mathrm{~m}),-9.1(4.75 \mathrm{~m})$ and $-9.5(9.75 \mathrm{~m})$.

The ST151 platform complex had a well defined light field near the surface (Fig. 4d) with the maximum amount of light coming from the easternmost platform. The light levels decreased with increasing depth although the outline of the complex was still apparent at $9.75 \mathrm{~m}$. $\log _{10}$-transformed light measurements from the open water deployment were $-8.1(0.75 \mathrm{~m}),-8.5$ $(4.75 \mathrm{~m})$ and $-9.1(9.75 \mathrm{~m})$ for this survey.

\section{Irradiance profiles}

Artificial light from the platforms dominated the irradiance profiles in the water column at both platforms (Figs. $5 \& 6$ ). Compared to the open water control deployments, platforms appeared to contribute a large amount of light within the depth strata we surveyed. These intensities, while substantially less intense than those measured at twilight, were nonetheless 1 order of magnitude brighter than measurements at open water control sites. At MC582, the irradiance profile beneath Stn d14, which was located under the flare stack, was $10^{3}$ times more intense than the open water control profiles (Fig. 5). In general, all profiles at stations close to the platform revealed light intensities that were at least 1 order of magnitude greater than those measured at the open water site. The remaining survey records fell between the intensity from d14 and open water (Fig. 5). At ST151 we measured a pattern similar to that found at MC582 (Fig. 6). We recorded 


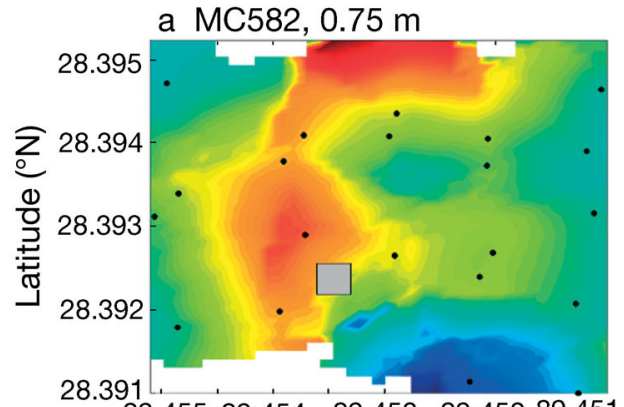

$89.45589 .454 \quad 89.453 \quad 89.45289 .451$ b MC582, $4.75 \mathrm{~m}$

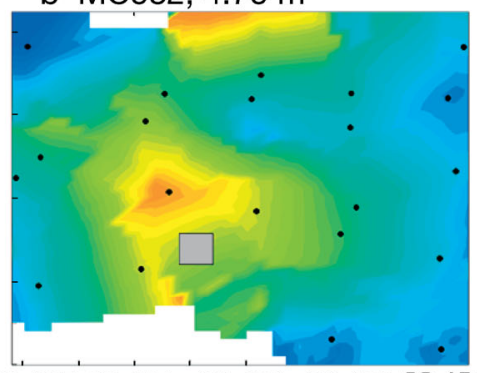

Longitude ( $\left.{ }^{\circ} \mathrm{W}\right)$

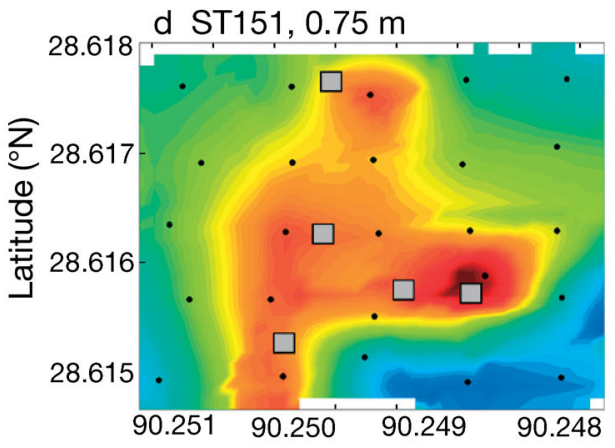

e ST151, $4.75 \mathrm{~m}$

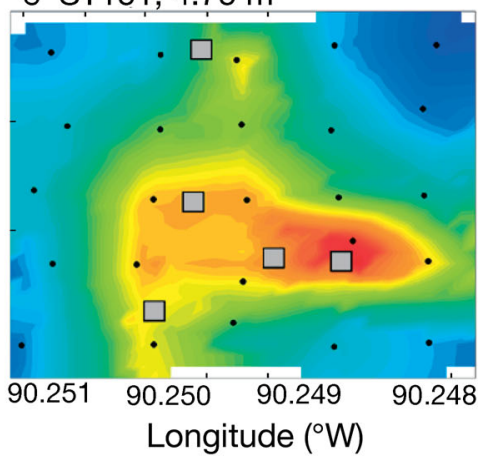

c MC582, $9.75 \mathrm{~m}$

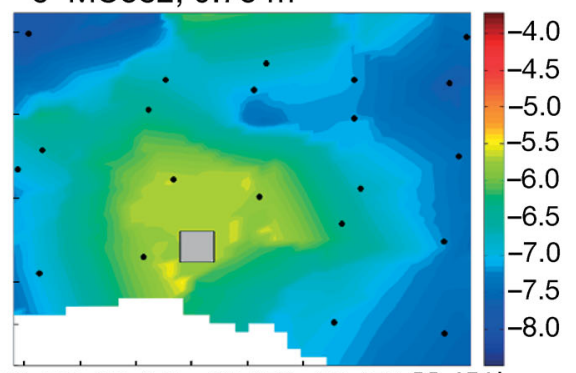

$1 \log _{10}$

(PAR)

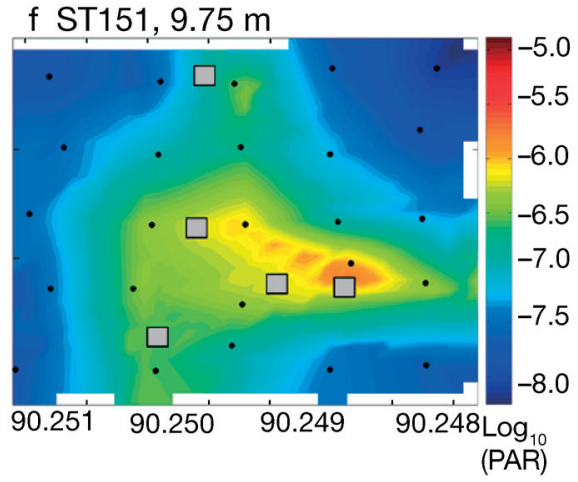

Fig. 4. Kriged map of $\log _{10}$ PAR for discrete depth strata $(0.75,4.75,9.75 \mathrm{~m})$ for $(\mathrm{a}-\mathrm{c}) \mathrm{MC} 582$ and $(\mathrm{d}-\mathrm{e})$ ST151. White areas indicate cells where error variance exceeded $0.15 ;(\bullet)$ deployment locations and $(\square)$ platform positions. Color bars are scaled to the range of light over all depths within each survey

the brightest light at Stn d19 from 0 to $17 \mathrm{~m}$ (Fig. 6). Intensity profiles measured at other stations around the platform were generally lower than those recorded at d19 but were still substantially more intense than at the open water site.

\section{Fish irradiance thresholds}

Two studies of juvenile and adult scombrids (mackerels) indicated that they required the least amount of

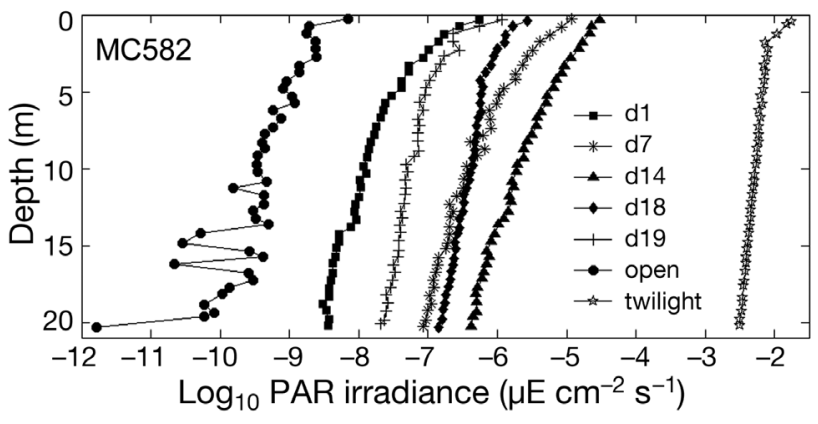

Fig. 5. $\log _{10}$ PAR irradiance by depth for MC582 (PAR: photosynthetically active radiation). Specific deployments made during survey (see Fig. 2a) including open water and twilight deployments light (-11.0 and $-10.7 \log _{10}$ PAR) to feed and school, respectively (Table 2). Juvenile carangids (jacks and scads) required more light, and the threshold for phototactic behavior by Decapterus maraudsi (Japanese scad) was $-6.7 \log _{10}$ PAR (Wenzao et al. 1982). This example was selected as an intermediate threshold. Job \& Bellwood (2000) provided an estimate of the light threshold for feeding in larval pomacentrids (damselfishes). Their mean value for 4 species (-7.5), was selected as the lower-level threshold (i.e. fishes requiring the least amount of light to feed). We used a

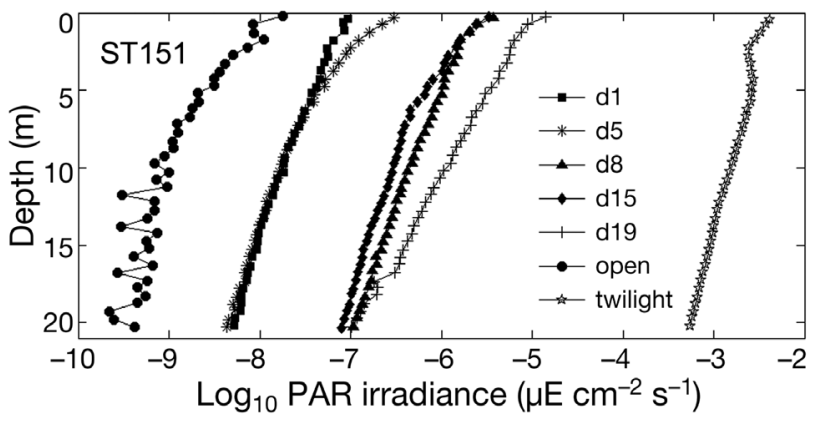

Fig. 6. $\log _{10}$ PAR irradiance by depth for ST151. Specific deployments made during survey (see Fig. 3a) including farfield open water and twilight deployments 
Table 2. Review of studies examining effect of light on feeding and schooling in fish species. Examples in bold selected to illustrate volume affected around the 2 platforms (Decapterus maruadsi, Clupea harengus, and 4 species of Pomacentridae). MLT: minimum light threshold. Rough conversions among other light units in the literature are: $1 \mu \mathrm{E} \mathrm{m} \mathrm{m}^{-2} \mathrm{~s}^{-1}=0.217 \mathrm{~W} \mathrm{~m}^{-2}=$ $51.2 \mathrm{lux}=4.78 \mathrm{ft}$ candles; $1 \mathrm{E}=1 \mathrm{~mol}$ of photons. All conversions refer to light in 400 to $700 \mathrm{~nm}$ (Valiela 1984)

\begin{tabular}{|c|c|c|c|c|}
\hline Species (size) & $\operatorname{MLT}\left(\mu E \mathrm{~cm}^{-2} \mathrm{~s}^{-1}\right)$ & $\log _{10}(\mathrm{MLT})$ & Behavior & Source \\
\hline \multicolumn{5}{|l|}{ Scombridae } \\
\hline \multicolumn{5}{|l|}{ Scomber scombrus } \\
\hline $310-340 \mathrm{~mm}$ & $1.8 \times 10^{-11}$ & -10.7 & Schooling & Glass et al. (1986) \\
\hline \multicolumn{5}{|l|}{ Pomacentridae } \\
\hline 4 spp. (approx. 12 mm) & $3.2 \times 10^{-8}$ & -7.5 & Feeding & Job \& Bellwood (2000) \\
\hline \multicolumn{5}{|l|}{ Carangidae } \\
\hline Trachurus symmetricus (100-140 mm) & $1 \times 10^{-9}$ & -9.0 & Feeding & Hunter (1968) \\
\hline $\begin{array}{l}\text { Decapterus maraudsi } \\
(100-120 \text { and } 220-250 \mathrm{~mm})\end{array}$ & $1.95 \times 10^{-7}$ & -6.7 & $\begin{array}{l}\text { Phototatic } \\
\text { behavior }\end{array}$ & Wenzao et al. (1982) \\
\hline \multicolumn{5}{|l|}{ Engraulidae } \\
\hline Engraulis mordax (larvae) & $1.19 \times 10^{-6}$ & -5.9 & Feeding & Bagarinao \& Hunter (1983) \\
\hline \multicolumn{5}{|l|}{ Clupeidae } \\
\hline Clupea harengus (13-17) mm & $1.95 \times 10^{-6}$ & -5.7 & Feeding & Blaxter (1968) \\
\hline \multicolumn{5}{|l|}{ Sciaenidae } \\
\hline Cynoscion regalis (larvae) & $5 \times 10^{-6}$ & -5.3 & Feeding & Connaughton et al. (1994) \\
\hline
\end{tabular}

threshold for larval Clupea harangus (Atlantic herring), which require $-5.7 \log _{10}$ PAR to feed (Blaxter 1968) as the upper threshold.

These 3 irradiance levels (low: -7.5 , intermediate: -6.7, high: -5.7 ) provided isolume boundaries that defined volumes of water within which sufficient light was available to enable the behavior of interest (Figs. 7 \& 8). At MC582, only $7.6 \%$ of the total volume (4691 of 61920 cells) would have contained enough light for feeding by fishes with a sensitivity comparable to larval herring Clupea harengus (Fig. 7a). Phototaxic behavior by fishes with phototaxic thresholds similar to that of Decapterus maraudsi would have been possible in $47.2 \%$ of the volume (29214 cells, Fig. 7b). There was sufficient light in $88.2 \%$ (54618 cells) for feeding by fishes that have sensitivities similar to larval pomacentrids (Fig. 7c). The corresponding volumes of water available for these activities were: $2.55 \times 10^{5}, 1.58 \times$ $10^{6}$, and $2.97 \times 10^{6} \mathrm{~m}^{3}$, respectively. In Fig. 7, contour lines indicate the 3 thresholds for representative depth bins at MC582 $(0.25,4.25,8.25,12.25,16.25,20.25 \mathrm{~m}$; Fig $7 d-i)$. At ST151 the survey contained 43560 total cells of which $1.4 \%$ (592 cells, Fig. 8a), 28.7\% (12511 cells, Fig. 8b) and 72.8\% (31733 cells, Fig. 8c) contained values bright enough for the corresponding behaviors, respectively. This equated to $3.22 \times 10^{4}, 6.81$ $\times 10^{5}$, and $1.73 \times 10^{6} \mathrm{~m}^{3}$ affected by the platform lights. The contour lines in Fig. 8 indicate the 3 thresholds for representative depth bins at ST151 $(0.25,4.25,8.25$, 12.25, 16.25, $20.25 \mathrm{~m}$; Fig 8d-i). These estimates must be viewed as conservative because the volume influ- enced by the lights often appeared to extend beyond the boundaries of the kriged volume.

\section{DISCUSSION}

This study provides the first known assessment of the artificial light field around offshore petroleum platforms in the northern Gulf of Mexico. Through use of a profiling photometer, predetermined sampling protocols, and geostatistical visualization, we propose that the light emitted near platforms produces a substantial artificial, physical gradient in the nocturnal marine environment. In turn, this irradiance gradient may provide fishes and other marine organisms beneath the platform with a profoundly altered nocturnal environment. The light fields reported here were measured under weather and sea-state conditions specific to our sampling trips and would vary under different circumstances. Increases in surface roughness and wave height would generally reduce underwater irradiance, while calm, flat seas would increase light penetration.

\section{Spectral comparison}

The source of light reaching the water's surface, even at the edge of our surveys, was the artificial light from the platforms. At ST151, this was light from the floodlights and at MC582 light was from the combination of a natural gas flare and floodlights. Platforms use 

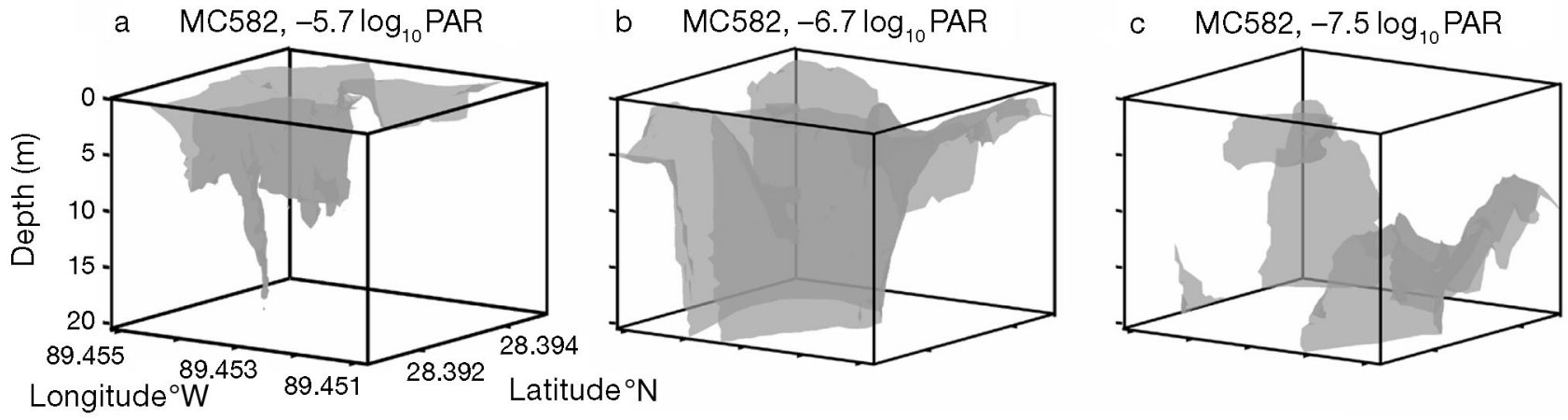

d $0.25 \mathrm{~m}$

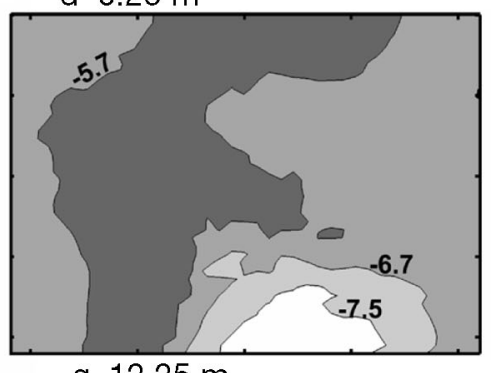

g $12.25 \mathrm{~m}$

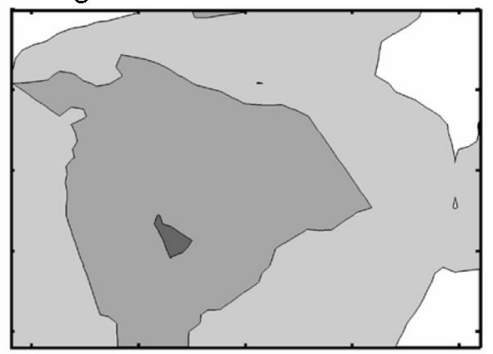

e $4.25 \mathrm{~m}$

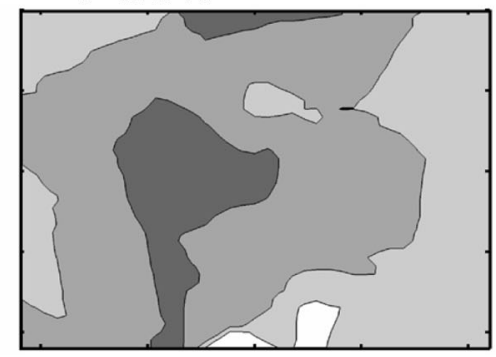

h $16.25 \mathrm{~m}$

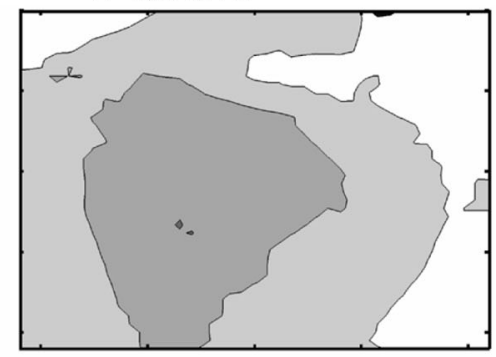

$f 8.25 \mathrm{~m}$

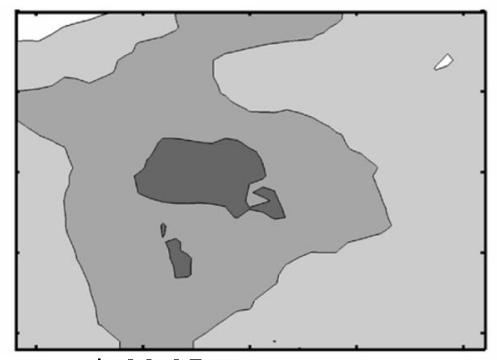

i $20.25 \mathrm{~m}$

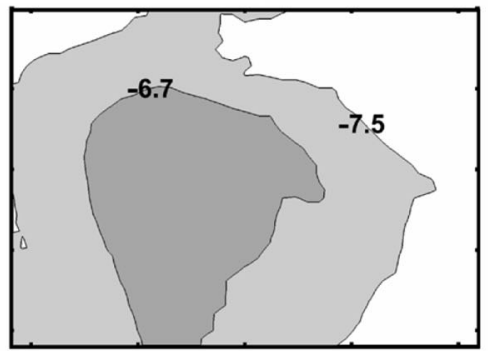

Fig. 7. Isosurface view from MC582 survey of $\log _{10}$ PAR thresholds for 3 fish groups. (a) Clupea harengus ( -5.7 log ${ }_{10}$ PAR threshold), (b) Decapterus maruadsi (-6.7 $\log _{10}$ PAR threshold), (c) Pomacentridae, 4 spp. ( $7.5 \log _{10}$ PAR threshold), (d-i) Cross-section views for 6 depth strata; contour lines indicate light threshold boundaries. $y$-axis represents longitude and $x$-axis latitude

2 varieties of floodlights: high pressure sodium or mercury vapor. High pressure sodium lights emit yelloworange light as seen by the human eye, whereas mercury vapor lights emit a perceptually blue-white light. The ST151 platform used both types of lights throughout the structures. The MC582 platform also had floodlights visible during sampling; however the light from the natural gas flare was much brighter. The spectral signature of the light we measured at the surface beneath MC582 was dominated by orange and red wavelengths, which matched those of the flare stack as recorded by the surface reference radiometer.

While light from the moon may provide a sufficient amount of light for feeding and schooling in some larval marine fishes (Hunter 1968, Macy et al. 1998), the intensity of the moonlight during the ST151 survey was lower than that of the floodlights. Moreover, the spectral characteristics of the moonlight and floodlights differed. Moonlight showed peaks in irradiance at 510 and $665 \mathrm{~nm}$, while the floodlights had peaks at 443 and $555 \mathrm{~nm}$. The intensity of artificial light can overwhelm any influence of the moon, particularly during lunar phases when the moon is not bright. Hernandez \& Shaw (2003) used light traps to collect ichthyoplankton at platforms and noted greater ichthyoplankton densities during new versus full moons. They also noted that lights of the platforms may have influenced their results because they were fishing a light trap within a giant 'light trap'.

\section{Spatial irradiance patterns}

We used ordinary point kriging in this study because of its ability to produce the best linear unbiased estimate of light at each grid point, as well as an estimate of the associated error variance (Bailey \& Gatrell 1995, Greene et al. 1998). Kriging has been widely employed 

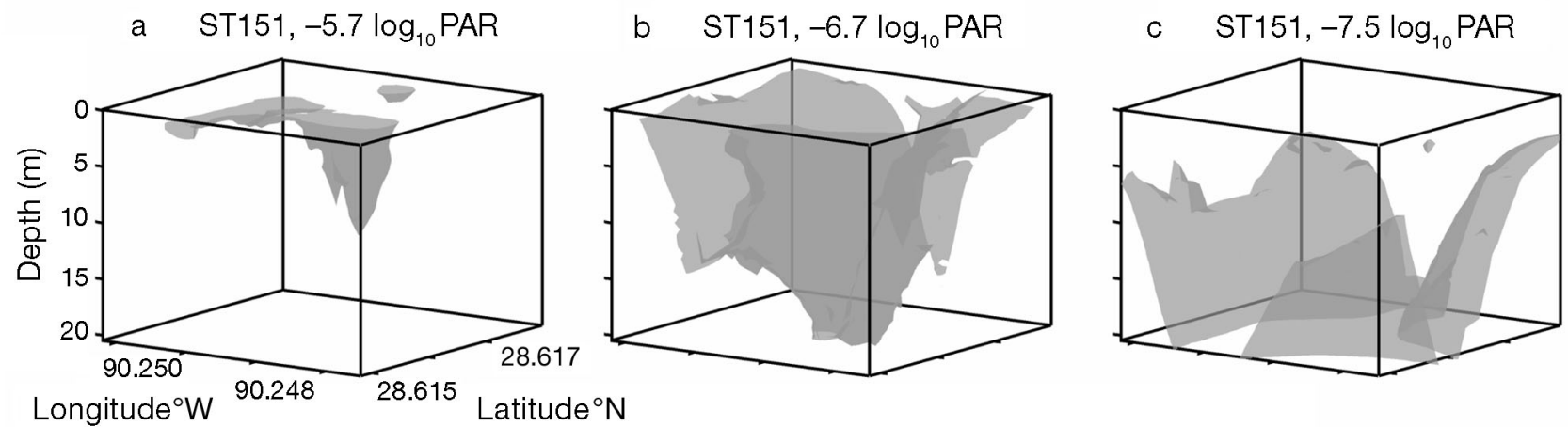

d $0.25 \mathrm{~m}$

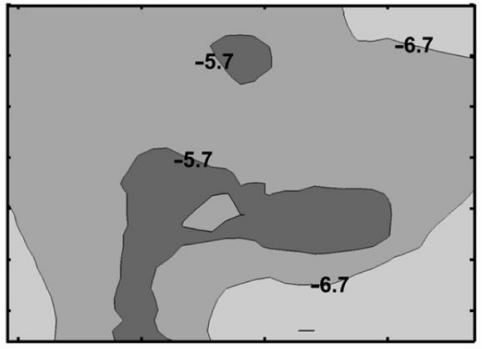

e $4.25 \mathrm{~m}$

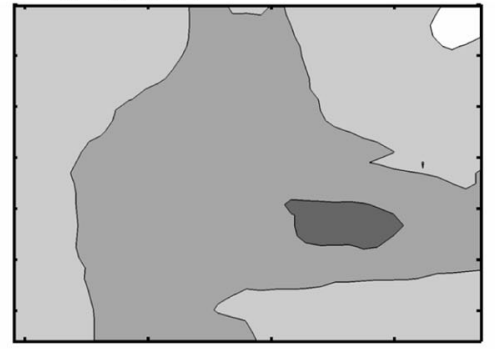

f $8.25 \mathrm{~m}$

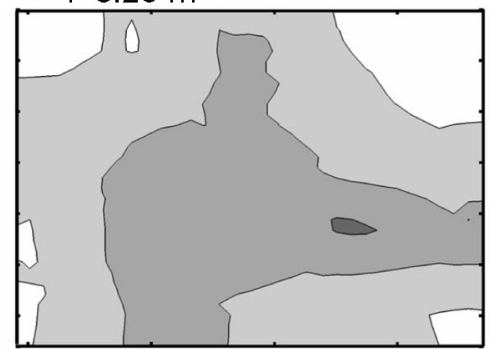

h $16.25 \mathrm{~m}$
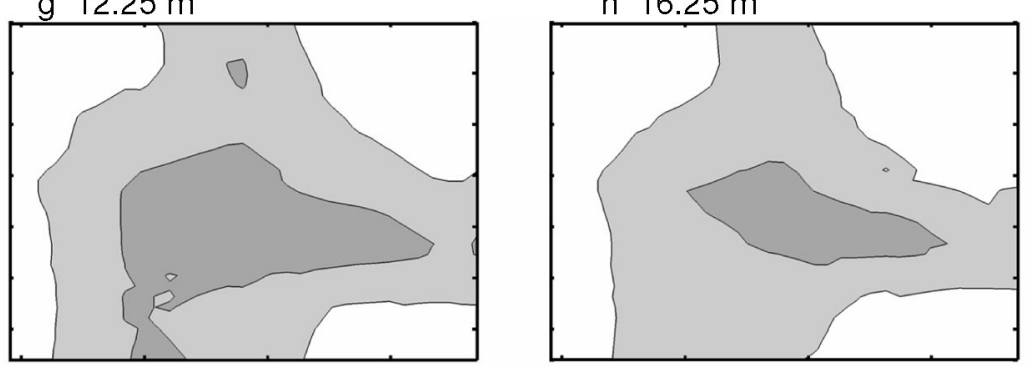

i $20.25 \mathrm{~m}$

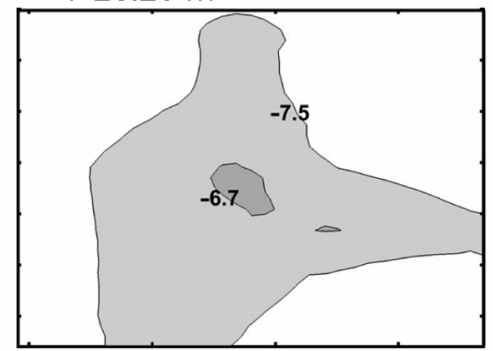

Fig. 8. Isosurface view from ST151 survey of $\log _{10}$ PAR thresholds for 3 fish groups. (a) Clupea harengus $\left(-5.7\right.$ log ${ }_{10}$ PAR threshold), (b) Decapterus maruadsi (-6.7 $\log _{10}$ PAR threshold), (c) Pomacentridae, 4 spp. ( $7.5 \log _{10}$ PAR threshold), (d-i) Crosssection views for 6 depth strata; contour lines indicate light threshold boundaries

as an objective interpolation scheme in oceanographic studies (e.g. Fletcher \& Sumner 1999, Heffernan et al. 2004). The patterns that kriging produced appeared to correspond to the distribution of artificial light around the platforms. For example, at MC582, the maximum area of PAR intensity was observed near the d14 sampling location, which was nearest to the flare. This interpolation also introduced some artifacts in the visualized volumes, such as the artificially high light region at the northern edge of the MC582 grid. At ST151, the light near the platform was not as bright as the MC582 gas flare, but the outline of the complex was well defined at the surface. The brightest light came from the compressor platform, which had the greatest number of floodlights (authors' pers. obs.). The kriged map indicated that light levels greater than $-6.0 \log _{10}$ PAR extended in many directions beyond $100 \mathrm{~m}$ from the nearest structure.
The distance around the platform that is influenced by artificial light is an important measurement. The boundary of the influence of light from the platforms can be estimated by determining where light levels drop to intensities comparable to open water background levels and where spectral signatures shift to correspond to moonlight. At MC582, light levels from deployments on the SE and NE edge of this survey approached the open water irradiance levels below 5 to $10 \mathrm{~m}$; however, it appeared that the light from the flare encompassed almost the entire area of our survey. The darkest portion of the interpolated field was still 10 times brighter than the darkest portion of the open water deployment for these depth strata. This first approximation of the light field around a deep-water platform with a gas flare suggests that a sampling grid should contain points greater than $250 \mathrm{~m}$ from the light source. 


\section{Irradiance profiles}

While the kriged maps indicated that the light field's horizontal extent reached the boundaries of our survey, the irradiance profiles suggested that platform light also extended below our maximum deployment depth. The maximum depth of $20.5 \mathrm{~m}$ was selected because adult Caranx crysos (Carangidae), a species we are currently studying, are generally caught in the upper $20 \mathrm{~m}$ around platforms (Keenan et al. 2003). These fish fed both during the day and at night near manned platforms. During this study, our measured survey profiles revealed irradiance levels that fell between twilight and open water levels. None of the measured irradiances beneath either platform were as low as those at comparable depths from open water sites. This suggests that one would have to sample much deeper in order to measure light levels that approached those found at a distance from platforms in open water.

\section{Biological significance}

The light intensity threshold for feeding and predator avoidance varies widely among teleost larvae (Blaxter 1986). Sampling methodologies for ichthyoplankton take this information into account where studies use a combination of nets and light traps to collect pelagic larvae as well as settlement-size larvae which may be competent enough to avoid a passively towed net (Choat et al. 1993, Hernandez \& Shaw 2003, Lindquist \& Shaw 2005). Hernandez \& Shaw (2003) showed consistently larger individuals of the same species collected by light traps versus nets. The examples we selected from our summary represented species and individuals sized similar to those sampled by Hernandez \& Shaw (2003) near platforms in the northern Gulf. The range of thresholds provided a 100× difference in light requirement for specific behaviors. Our results show that, depending on species and platform, the volume of water impinged by the light field can vary greatly. Larval clupeids, which required the most amount of light to feed, would have received little benefit from the platform lights, and light-limited behaviors would likely have been restricted to waters near the surface. Larval pomacentrids and carangids would gain the most from the light field because a larger volume contained sufficient light for feeding. Studies of ichthyoplankton near offshore platforms have attempted to sample outside the light field using light traps fished $20 \mathrm{~m}$ downcurrent from the platform (Hernandez \& Shaw 2003, Lindquist et al. 2005). Our results indicate that $20 \mathrm{~m}$ is likely not far enough away to sample waters outside the platform's 'halo of light'.
Platforms have long been considered optimal angling environments for commercial and recreational fisheries (Stanley \& Wilson 1990). Utilizing hydroacoustics, Stanley \& Wilson (1997) showed the adult fish densities were highest near to the platforms, decreased significantly beyond $30 \mathrm{~m}$, and that there were no changes in fish density over $24 \mathrm{~h}$ cycles. While our results do not reference light requirements for adult fishes, a previous study indicated that adult carangids common around platforms consume large proportions of fishes and macroinvertebrate zooplankton during the night (Keenan et al. 2003). Platforms may be providing an enhanced foraging environment for larval, juvenile and adult fishes by providing sufficient light to locate and capture prey, as well as by concentrating positively phototaxic prey taxa. Wilson et al. (2003) found significantly greater fish densities around a standing, manned platform than near 2 'reefed' platforms (platforms that have been decommissioned and either cut below the surface or toppled to create artificial reefs) and a natural reef in the same area. This difference was explained by a 'loss' of pelagic planktivores from the upper $50 \mathrm{~m}$ when a platform is 'reefed'. These pelagic species (i.e. jacks, mackerels) would be likely to benefit most from platform lights. For larvae and juvenile fishes there is probably a trade-off between living and foraging in an artificially illuminated nocturnal environment. The increased illumination likely allows them to feed on zooplankton that have concentrated within the light field near the surface; however, the same light may make them more vulnerable to larger predators such as mackerels, jacks, and snappers (Stanley \& Wilson 1997, Keenan et al. 2003).

\section{Summary}

In summary, this project has demonstrated that the artificial light field around offshore petroleum platforms can be quantified and visualized using field sampling and geostatistics. Our results suggest that the artificial light field extends beyond the edge of our survey (>100 $\mathrm{m}$ for ST151 and >200 $\mathrm{m}$ for MC582). These results are likely to be important to the associated fish community, which may gain a trophic subsidy through an extended foraging opportunity after dark. This 'visual subsidy' will vary among species depending on visual intensity thresholds and developmental stage. Additionally, the light fields around platforms will also vary under a range of sea-states and atmospheric conditions. Future research will examine the movement patterns and diel site-fidelity of adult, pelagic fishes around ST151. Further understanding of these movements will provide insight into how fishes utilize the platform environment over the diel cycle and whether they exploit this nocturnal physical gradient. 
Acknowledgements. We acknowledge a grant to S.F.K. and M.C.B. from the J. Bennett Johnston Science Foundation. Access to ST151 was provided as part of a research grant to M.C.B. and S.F.K. by the Minerals Management Service through the LSU Coastal Marine Institute. We would like to thank J. B. Holley, J. Malbrough, A. T. Adamack, the Chevron Corporation and the crew of ST151 for field assistance. The radiometer was provided through a loan from Biospherical Instruments. Thanks to John Morrow and James Robertson of Biospherical Instruments for technical assistance with hardware/software application.

\section{LITERATURE CITED}

Bagarinao T, Hunter JR (1983) The visual feeding threshold and action spectrum of northern anchovy (Engraulis mordax) larvae. Calif Coop Ocean Fish Investig Rep 24: 245-254

Bailey TC, Gatrell AC (1995) Interactive spatial data analysis, John Wiley \& Sons, New York

Blaxter JHS (1968) Visual thresholds and spectral sensitivity of herring larvae. J Exp Biol 48:39-53

Blaxter JHS (1986) Development of sense organs and behavior of teleost larvae with special reference to feeding and predator avoidance. Trans Am Fish Soc 115:98-114

Bohnsack JA (1989) Are high densities of fishes at artificial reefs the result of habitat limitation or behavioral preference? Bull Mar Sci 44:631-645

Choat JH, Doherty PJ, Kerrigan BA, Leis JM (1993) A comparison of towed nets, purse seine, and light-aggregation devices for sampling larvae and pelagic juveniles of coral reef fishes. Fish Bull (Wash DC) 91:195-209

Connaughton VP, Epifanio CE, Thomas R (1994) Effects of varying irradiance on feeding in larval weakfish (Cynoscion regalis). J Exp Mar Biol Ecol 180:151-163

Fletcher WJ, Sumner NR (1999) Spatial distribution of sardine (Sardinops sagax) eggs and larvae: an application of geostatistics and resampling to survey data. Can J Fish Aquat Sci 56:907-914

Franks JS (1999) A review: pelagic fishes at petroleum platforms in the northern Gulf of Mexico; diversity, interrelationships, and perspectives. In: Le Gall JL, Cayre P, Taquet $M$ (eds) Pêche thonière et dispositifs de concentration de poissons. IFREMER, Martinique, p 502-515

Gallaway BJ (1980) Pelagic, reef and demersal fishes, and macro-crustaceans/biofouling communities. Report No. NMFS-SEFC-48, LGL Ecological Research Associates, Bryan, TX

Glass CW, Wardle CS, Mojsiewicz WR (1986) A light intensity threshold for schooling in the Atlantic mackerel, Scomber scombrus. J Fish Biol 29:71-81

Greene $\mathrm{CH}$, Wiebe $\mathrm{PH}$, Pelkie C, Benfield MC, Popp JM (1998) Three-dimensional acoustic visualization of zooplankton patchiness. Deep-Sea Res II 45:1201-1217

Hastings RW, Ogren LH, Mabry MT (1976) Observations on the fish fauna associated with offshore platforms in the northeastern Gulf of Mexico. US Natl Mar Fish Serv Fish Bull 74:387-402

Heffernan OA, Danilowicz BS, Milligan SP (2004) Determination of species-specific spawning distributions of commercial finfish in the Irish Sea using a biochemical proteinbased method. Mar Ecol Prog Ser 284:279-291

Hernandez JFJ, Shaw RF (2003) Comparison of plankton net and light trap methodologies for sampling larval and juvenile fishes at offshore petroleum platforms and a coastal jetty off Louisiana. Am Fish Soc Symp 36:15-38
Hernandez JFJ, Shaw RF, Cope JS, Ditty JG, Farooqi T, Benfield MC (2003) The across-shelf larval, postlarval, and juvenile fish assemblages collected at offshore oil and gas platforms west of the Mississippi River delta. In: Stanley D, Scarborough-Bull A (eds) Fisheries, reefs, and offshore development. Am Fish Soc Symp 36:39-72

Hunter JR (1968) Effects of light on schooling and feeding of jack mackerel, Trachurus symmetricus. J Fish Res Board Can 25:393-407

Job SD, Bellwood DR (2000) Light sensitivity in larval fishes: implications for vertical zonation in the pelagic zone. Limnol Oceanogr 45:362-371

Keenan SF, Benfield MC, Shaw RF (2003) Zooplanktivory by blue runner Caranx crysos: a potential energetic subsidy to Gulf of Mexico fish populations at petroleum platforms. In: Stanley DR and Scarborough-Bull A (eds) Fisheries, reefs, and offshore development. Am Fish Soc, Symp 36, Bethesda, MD, p 167-180

Lindberg WJ (1997) Can science resolve the attractionproduction issue? Fisheries 22:10-13

Lindquist D, Shaw R (2005) Effects of current speed and turbidity on stationary light-trap catches of larval and juvenile fishes. Fish Bull (Wash DC) 103:438-444

Lindquist D, Shaw, R, Hernandez, F (2005) Distribution patterns of larval and juvenile fishes at offshore petroleum platforms in the north-central Gulf of Mexico. Estuar Coast Shelf Sci 62:655-665

Love MS, Caselle J, Snook L (1999) Fish assemblages on mussel mounds surrounding seven oil platforms in the Santa Barbara channel and Santa Maria Basin. Bull Mar Sci 65: 497-513

Love MS, Caselle JE, Snook L (2000) Fish assemblages around seven oil platforms in the Santa Barbara Channel area. Fish Bull (Wash DC) 98:96-117

Macy WK, Sutherland SJ, Durbin EG (1998) Effects of zooplankton size and concentration and light intensity on the feeding behavior of Atlantic mackerel Scomber scombrus. Mar Ecol Prog Ser 172:89-100

Olney RR (1981) Offshore! Oil and gas platforms in the ocean, E.P. Dutton, New York

Rountree RA (1990) Community structure of fishes attracted to shallow water fish aggregation devices off South Carolina, USA. Environ Biol Fish 29:241-262

Scarborough-Bull A, Kendall JJ Jr (1994) An indication of the process: offshore platforms as artificial reefs in the Gulf of Mexico. Bull Mar Sci 55:1086-1098

Shipp RL (1999) The artificial reef debate: are we asking the wrong question? Gulf Mex Sci 1:51-55

Stanley DR, Wilson CA (1990) A fishery-dependent based study of fish species composition and associated catch rates around oil and gas structures off Louisiana. Fish Bull (Wash DC) 88:719-730

Stanley DR, Wilson CA (1996) Abundance of fishes associated with a petroleum platform as measured with dual-beam hydroacoustics. ICES J Mar Sci 53:473-475

Stanley DR, Wilson CA (1997) Seasonal and spatial variation in the abundance and size distribution of fishes associated with a petroleum platform in the northern Gulf of Mexico. Can J Fish Aquat Sci 54:1166-1176

Stanley DR, Wilson CA (2000) Seasonal and spatial variation in the biomass and size frequency distribution of the fish associated with oil and gas platforms in the northern Gulf of Mexico. Report No. MMS 00-005, Minerals Management Service, Gulf of Mexico OCS Region, New Orleans, LA

Tolan JM (2001) Patterns of reef-fish larval supply to petroleum platforms in the northern Gulf of Mexico. PhD dis- 
sertation. Louisiana State University, Baton Rouge, LA

US Geological Survey (Florida Caribbean Science Center) (2002) Potential for Gulf of Mexico deepwater petroleum structures to function as fish aggregating devices (FADs). Report Nos. USGS BSR 2001-008 and MMS 01-008. Minerals Management Service, Gulf of Mexico OCS Region, New Orleans, LA

Valiela I (1984) Marine ecological processes, Springer-Verlag, New York

Editorial responsibility: Jon Hare (Contributing Editor), Narragansett, Rhode Island, USA
Wenzao Y, Daren H, Yushui Z (1982) Studies on the phototactic behavior of round scad and chub mackerel. Acta Oceanol Sin 1:275-281

Wilson CA, Pierce A, Miller MW (2003) Rigs and reefs: a comparison of the fish communities at two artificial reefs, a production platform, and a natural reef in the northern Gulf of Mexico. Report No. 03-009, Minerals Management Service, Gulf of Mexico OCS Region, New Orleans, LA

Submitted: October 17, 2005; Accepted: May 22, 2006

Proofs received from author(s): January 22, 2007 